\title{
COLUBER FASCIATUS.
}

-

CHARACTER GENERICUS.

Scuta abdominalia.

Squame fubcaudales.

$$
\text { Lin. Syf. Nat. p. } 275 .
$$

CHARACTER SPECIFICUS, E'c.

COLUBER CÆRULEUS, fubtus pallidior, cæruleo lucidiore variatus. COLUBER FASCIATUS ?

ANGUIS e cæruleo et albo varius.

$$
\text { Lin. Syft. Nat. p. } 378 .
$$

$$
\text { Cateß. 2. t. } 5^{8} \text {. }
$$

Hiftoriam naturalem probe callentibus facile patebit a Catefbro mutuatos effe nos figuram hujus ferpentis, fitu paululum mutato. Eadem communiter putatur hæe fpecies ac coluber fafciatus Linnæi; ipfeque Linnæus, nonnibil tamen addubitans, relegat lectores ad hanc ipfam Catefbæi tabulam. $\mathrm{Si}$ veros colores depinxerit Caterbæus, habendus 
proculdubio eft coluber fafciatus inter formofiffimos fui generis. Reperiri præcipue dicitur in Carolina, et in numero effe ferpentum prorfus innacuorum. 



\title{
THE \\ FASCIATED SNAKE.
}

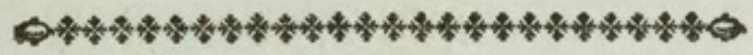

GENERIC CHARACTER.

Tranfverfe Lamella under the abdomen. Broad alternate Scales under the tail.

\section{SPECIFIC CHARACTER, छC.}

BLUE SNAKE, paler and variegated with brighter blue beneath.

The WAMPUM SNAKE.

Cateß. Car. 2. t. $5^{8 .}$

It will readily be perceived by thofe who are converfant in natural hiftory, that the elegant fnake reprefented on the prefent plate is in reality copied from Catefby, with the variation only of pofture: it is commonly confidered as the coluber fafciatus of Linnæus, and is thus quoted, though not without a mark of uncertainty, in the Syftema Naturæ. If the colours of the living animal are really fuch as expreffed by Caterby, it muft certainly be regarded as

one 
one of the moft beautiful of that variable tribe. It is faid to be found principally in Carolina, and is a perfectly harmlefs fpecies. 


\section{$2 \mathrm{BHL}$ Biodiversity Heritage Library}

Shaw, George. 1797. "The Fasciated Snake, Coluber fasciatus [PI. 266]." The Naturalist's Miscellany 8(LXXXIX), https://doi.org/10.5962/p.310809.

View This Item Online: https://www.biodiversitylibrary.org/item/276320

DOI: https://doi.org/10.5962/p.310809

Permalink: https://www.biodiversitylibrary.org/partpdf/310809

\section{Holding Institution}

Museums Victoria

\section{Sponsored by}

Atlas of Living Australia

\section{Copyright \& Reuse}

Copyright Status: Public domain. The BHL considers that this work is no longer under copyright protection.

This document was created from content at the Biodiversity Heritage Library, the world's largest open access digital library for biodiversity literature and archives. Visit BHL at https://www.biodiversitylibrary.org. 